Revue d'histoire de l'Amérique française

ZRS REVUE D.HISTOIRE DE L'AMÉRIQUE FRANÇAISE

\title{
Sewell et son projet d'asservir le clergé canadien (1801)
}

\section{Jean-Pierre Wallot}

Volume 16, numéro 4, mars 1963

URI : https://id.erudit.org/iderudit/302230ar

DOI : https://doi.org/10.7202/302230ar

Aller au sommaire du numéro

Éditeur(s)

Institut d'histoire de l'Amérique française

ISSN

0035-2357 (imprimé)

1492-1383 (numérique)

Découvrir la revue

Citer cet article

Wallot, J.-P. (1963). Sewell et son projet d'asservir le clergé canadien (1801).

Revue d'histoire de l'Amérique française, 16(4), 549-566.

https://doi.org/10.7202/302230ar d'utilisation que vous pouvez consulter en ligne.

https://apropos.erudit.org/fr/usagers/politique-dutilisation/ 


\section{SEWELL ET SON PROJET D'ASSERVIR LE CLERGÉ CANADIEN (1801)}

Trop d'historiens ont sous-estimé le lieutenant-gouverneur Milnes et son administration. Celle-ci dura six ans, de 1799 à 1805. Plutôt paisible en surface, de graves tensions la crispaient en profondeur. L'irruption de 1805 ne fit que répercuter un pugilat qui couvait depuis longtemps. Quant à Milnes, on l'a affublé de traits de caractère tout à fait incongrus, compte tenu de son mandat. On l'a cru mou, placide, un peu naïf, certainement peu brillant. Pourtant, le premier peut-être, il chercha à diagnostiquer les maladies qui rongeaient la colonie et à les en extirper systématiquement.

Dans son investigation, Milnes bute toujours sur la même cause fondamentale de l'inefficacité de la constitution: la carence d'une aristocratie forte, dynamique et influente. En effet, la tenure seigneuriale a nivelé les classes et rogné peu à peu la fortune et l'influence des seigneurs; l'Eglise esquive toute emprise directe de la Couronne sur elle, à l'encontre des instructions royales; enfin, on a licencié la milice, après la conquête, amorce de sa décadence et de celle de ses capitaines. Pour débusquer ces maux, il faudrait d'abord stimuler la montée d'une aristocratie riche, capable de contrebalancer l'élément populaire à la législature. D'autres remèdes s'imposent: sujétion de l'Eglise à la prérogative royale; revalorisation de la fonction de capitaine de milice; manipulation d'un clergé en laisse et des capitaines d'une milice réformée de façon à «mouler» la masse et lui faire élire une majorité pro-gouvernementale à l'Assemblée; enfin, peuplement britannique dans les cantons et accroissement des dépenses civiles. ${ }^{1}$

\footnotetext{
1 Milnes à Portland, Québec, 1er novembre 1800, Archives publiques du Canada [AC], Q. 85: 228-245. Traduction: Arthur G. Doughty et Duncan A. McArthur, Documents relatifs $\grave{a}$ l'Histoire constitutionnelle $d u$ Canada, 1791-1818 (Ottawa, 1915), 252-258. A l'avenir: D.C. (II).
} 
Le secrétaire d'État aux colonies ne peut qu'applaudir à de si louables intentions, en particulier sur le plan religieux:

Je considère qu'il est non seulement très important mais absolument nécessaire de rétablir ce pouvoir [nomination aux cures] que le gouverneur devra exercer, et d'exiger l'autorisation requise pour entrer dans les ordres sacrés, et je dois vous demander de vous efforcer de faire observer cette partie des instructions par tous les moyens que permet la prudence. C'est donc vous dire que je serai heureux de voir adopter votre proposition d'augmenter l'allocation de l'évêque catholique, si une augmentation de ce genre, quelque considérable qu'elle soit, doit avoir l'effet de restituer au représentant du roi au Canada ce pouvoir et ce contrôle essentiellement nécessaires à l'exercice de son autorité... ${ }^{2}$

Avec la constitution de 1791, Pitt a espéré naïvement une «conversion» naturelle des Canadiens: c'est-à-dire leur assimilation spontanée, sans douleur ni pression de l'extérieur. Plus pratique, Milnes table sur une évidence que ressassent les marchands canadians depuis longtemps : pour aboutir à l'objectif de Pitt, il faudra un effort long et méthodique. Le lieutenantgouverneur ne se contente donc pas de ruminer des velléités et de pontifier sur la gravité de la situation. Dès 1801, habilement, sans panache, il embraye la colonisation dans une offensive "britannisante". Il évite pourtant de bousculer les Canadiens. $\mathrm{Au}$ contraire, il se les concilie. Sauf en 1805, lors de la querelle des prisons, et à l'occasion d'accrochages mineurs, aucun déchaînement des passions ou plus exactement des exigences nationales, sous son administration. Elles se contentent de grésiller, comme la mèche d'un explosif.

L'exécutif anglais, Sewell en tête, veut incruster dans la réalité les conséquences inéluctables de 1760 , quarante ans après le fait. Il commence à concrétiser ce plan dès 1801. L'offensive est globale, structurée, tout comme l'organisme qu'on veut dé-

2 Portland à Milnes, Whitehall, 6 janvier 1801, AC, Q. 86-1: 3. Traduction: D.C. (II), 258-261. 
molir, puis assimiler. Elle embrasse la vie politique, économique, sociale, culturelle et religieuse. Elle ne lanternera qu'à cause d'une lacune capitale: la lenteur du peuplement britannique dans le Bas-Canada, condition préalable au brassage des populations et à l'absorption des conquis. Délai et incurie qui cravachent le nationalisme canadien-français, et ultimement, leur survie. Stupide, distraite ou crédule, la Chambre d'assemblée ne le sera pas toujours. $\AA$ partir de 1805 , elle se blindera contre la trouée « of the Canada». Londres devra intervenir. On y songera davantage en 1810, après l'échec du plan d'action de 1800. À ce moment-là, toutefois, c'est la constitution elle-même que l'on remettra en question, non les modalités de son application.

A partir de 1801, le parti des colonisateurs britanniques déclenche donc une offensive concertée contre l'épave de la colonisation française, cuirassée dans son particularisme par deux constitutions successives (1774 et 1791): assiduité-record des représentants anglais en Chambre, ce qui les catapulte à une ou deux voix de la majorité absolue - la plupart des Canadiens ont déserté Québec après les premiers jours de la session; l'Institution royale, «cuisinée» par Mountain et l'exécutif depuis 1799, combattue par la quasi-totalité des Canadiens présents en Chambre $;^{3}$ l'acte des «lods et ventes ou des droits de mutation », avec comme objectifs une hausse des revenus, l'effritement du régime seigneurial et la fusion des conquis dans le groupe canadian; ${ }^{4}$ obstruction des Britanniques contre la loi sur les tes-

3 Voir le Journal de la Chambre d'Assemblée du Bas-Canada (Québec, 1801), 145-147, 167, 173-175, 193-199, 225, 239-241, 299-301, 369-379. A l'avenir: JCABC (1801).

4 Milnes à Portland, Québec, 16 avril 1801, AC, Q. 86-1: 157. Traduction: D.C. (II), 261-263. Rapport du procureur général Sewell, 4 avril 1801, AC, Q. 86-1: 175. Traduction: D.C. (II), 268-273. Milnes à Portland (« secrète »), Québec, 10 juin 1801, AC, Q. 87-1: 93. Traduction: D.C. (II), 159 , note 1 . 
taments et dernières volontés, ${ }^{5}$ et contre l'acte pour l'emploi du serment décisoire au civil $;{ }^{6}$ projet de réforme de la milice, ${ }^{7}$ etc.

Mais le feu ne crépitait pas sur les seuls fronts politique, économique, social et culturel. Restait le plan religieux. Milnes s'était hérissé contre l'indépendance du clergé vis-à-vis le pouvoir civil. Portland lui avait donné carte blanche: le lieutenantgouverneur pouvait arrondir «l'allocation de l'Evêque» selon les besoins; euphémisme à peine déguisé pour coiffer une simple opération de marchandage de consciences. Il fallait pourtant manœuvrer avec prudence et diplomatie. Milnes, Mountain, qui suppurait de zèle jaloux et de sainte indignation depuis 1793, Ryland, qui se gendarmait à la seule pensée des «papistes,$^{8}$ et Sewell, ce colonisateur lucide et suprêmement intelligent, s'embusquèrent à l'affût d'occasions propices à leurs desseins.

Or il arriva qu'à l'hiver 1801, les marguilliers de la paroisse catholique de Montréal sollicitèrent pour leur fabrique le droit de posséder en «main morte » un lot de terre et la «Maison Vaudreuil », achetés en 1773 à Montréal pour l'éducation des Canadiens. Ces biens, ils voulaient les y affecter à perpétuité. D'autre part, le gouvernement n'ignorait pas le désir de l'Église de tenir «en main morte » ses écoles et ses collèges, actuels et futurs. Un amendement intercalé dans le bill de l'Institution royale ne palissadait-il pas les institutions privées, déjà existantes ou à venir, contre cette loi ? ${ }^{9}$

Consultés par Milnes, les légistes de la couronne - Sewell, ${ }^{10}$ 5 Rapport
Q. 86-2: $249-256$.

6 Rapport du procureur général Sewell, Québec, 4 avril 1801, ibid.: 270-275. Milnes à Portland, Québec, 10 juin 1801, ibid.: 244.

7 P. R. St-Ours à M. De Lavaltrie, 29 avril 1802, AC, collection Baby [M.G. 22/6], 91:50. «Mémoire sur le service de la milice en cas de besoin 》, [s.a.], [s.d.], ibid., 111: 49.

8 « I call them Popish to distinguish them from the Clergy of the Established Church, and to express my contempt and detestation of a religion which sinks and debases the human mind, and which is a curse to every country where it prevails .... (Ryland à -, 23 décembre 1804, cité par R. Christie, History of Lower Canada [...] (6 vols., Québec, 1848-1855), 6: 72-73. A l'avenir, History.)

9 JCABC (1801), 299-301.

10 Sewell, le chef le plus prestigieux du parti anglais, était né aux Etats-Unis, à Cambridge, Mass., en 1766. Après des études en Angleterre, il se transplanta à nouveau, cette fois au Nouveau-Brunswick, où il aborda 
procureur général, et Foucher, ${ }^{11}$ solliciteur général - déconseillèrent un tel précédent. La capitulation de Québec, le traité de Paris et l'Acte de Québec ne garantissaient que ce qui était essentiel à la liberté du culte catholique. La «Maison Vaudreuil » ne s'imbriquait en aucune façon dans le culte ou les rites. Au contraire, on devait y dispenser l'enseignement aux jeunes, réalité étrangère à l'exercice de la religion et qui est «completely incompatible with their Institution, and the Duties of their Offices ». Le gouvernement pouvait octroyer des lettres d'amortissement, mais seulement pour la construction d'une église. ${ }^{12}$

Milnes dut vouloir scruter davantage le fond de la question. À sa demande, quelques jours plus tard, Sewell décortiqua l'ensemble de la situation religieuse, dans un rapport apparemment secret. ${ }^{13}$ Deux mesures capitales émergent surtout de ce plan d'action: usage par l'Etat de son droit de nomination aux cures, pour torpiller la puissance «cléricale» de l'évêque; «politisation » de l'évêque et du coadjuteur (sièges dans les conseils) avec pensions, pour écharper leur influence spirituelle sur le laïcat canadien. Le document s'ouvre sur des considérations

l'étude du droit sous Ward Chipman. Reçu avocat du Bas-Canada, en 1789 , il fut pistonné aux postes d'avocat général et d'inspecteur général du domaine royal, en 1793, puis de procureur et d'avocat général, en 1795 . Il siégea à l'Asssemblée, de 1796 à 1808, comme représentant du Bourg William Henry. En mai 1808, il était promu juge-en-chef de la province. L'Assemblée connaissait ses idées. Elle le mit en accusation, en 1814, de même que Monk, sur leur conduite judiciaire. Le Conseil privé débouta ces accusations. Et Sewell allait continuer à jouer un rôle prédominant dans la politique canadienne, jusqu'à sa mort, le 12 novembre 1839 . En 1810 et en 1824, il militera activement pour l'union des Canadas.

${ }^{11}$ Le solliciteur général (depuis 1795), un Canadien jugé «transfuge » par le parti patriote, devint juge provincial pour le district des TroisRivières, en 1802, et juge puîné, à la Cour du banc du roi de Montréal, en 1812. En 1817, la Chambre allait l'inculper d'incompétence et de partialité dans l'exercice de ses hautes fonctions. Elle finit par laisser tomber ces accusations.

12 Rapport du procureur général Sewell et du solliciteur général Foucher, Québec, 1er mai 1801, AC, R.G. 4, Série «S 》 [A1], 56A: 69.

13 Ce projet de dépouiller l'évêque de ses pouvoirs, daté du 29 mai 1801, semble inédit et inconnu des historiens. Il s'agit d'un brouillon, taraudé à certains endroits et maculé de ratures, que nous avons repéré dans les documents personnels de Sewell, aux archives d'Ottawa. Ni les dépêches officielles ni la correspondance interdépartementale n'en signalent l'existence. De là l'opinion avancée que ce rapport était secret, destiné au seul lieutenant-gouverneur. 
générales concernant l'Église catholique: elle se veut à l'abri de toute influence temporelle, distincte de l'État; d'où la menace pour ce dernier:

Quebec 29th May 1801.

\begin{abstract}
May it please Your Excellency,
When I had the honor of seeing your Excellency you was pleased to direct me to commit to paper the substance of my ideas respecting the present state of the Roman Catholic Church in Canada and the means which have occurred to me for placing it under sufficient restraint and direction.

The general system of the Church of Rome is an Imperium in Imperio. And the present situation of that Church in Canada is preeminently such. It is either a distant body from the state, an ecclesiastical authority without a shadow of temporal influence and as such an ... evil highly dangerous to the Government. Yet the present situation of Canada, where nineteen twentieths of the Inhabitants are Catholics, the subject is a matter of great delicacy. Something however it is evident must be done.
\end{abstract}

Il faut donc réagir au plus tôt. Or, le gouvernement qui était financièrement les ministres d'un culte, établit ce culte. C'est le cas du catholicisme romain, au Canada: l'Acte de Québec légalise la collection des dîmes. Il faut donc infléchir cet état de faits à l'avantage de la Couronne: et d'abord, en débiffant l'autorité actuelle des évêques sur le clergé et le peuple; en les conditionnant au patronage de la Couronne.

When the Government of a Country provides a fund in public authority for the maintenance of the ministers and teachers of any Religion, that Religion may (I fear with too much certainty) be said to be established. This is the case with respect to the R. Catholic Religion in Canada, the Quebec Act of 1774 having not only permitted the free exercise of that system but supported it by tythes. The political expediency therefore of its establishment in this Province need not be discussed. It is not only sanctioned but supported by Act of Parliament and the only question for consideration is 
by what means it can now be made subservient to the purpose of Government. The power of the R. C. Bishop at this moment is immense. He claims the universal Patronage of Church. He presents to every living in the Country \& exercices the rights of removing away every incumbant at pleasure. His influence over his subordinate clergy is consequently most extensive. He directs them at will, and the ... ignorance and superstition of the country, enable every parish priest to govern and head his flock as he is directed. The importance therefore of guiding the Bishop under such circumstances is obvious to direct him is to direct all. But at the same time, it is equally obvious that to suffer the Bishop to enjoy his present importance and thro' him to exercise an indirect influence over the inferior clergy is to make Endowment itself dependant upon the will and caprice of its own officer - This cannot be suffered, it is highly dangerous, contrary to every principle of sound policy and inconsistent with the very nature of Government - the general object (whatever may be the best means to effect it) must necessarily be to render the Bishop \& all his subordinate clergy equally dependant upon the Crown.

Les fonctions d'évêque et de coadjuteur s'avèrent nécessaires au Canada, et particulièrement pour épauler le gouvernement. Mais leurs titulaires ont usurpé une autorité illégale, nettement prohibée par des statuts explicites de la Grande-Bretagne. La conquête a fait basculer les pouvoirs de l'évêque dans les mains de la couronne. Celle-ci doit assumer ce droit, jusqu'ici purement théorique, d'assigner aux cures et à l'épiscopat. De cette façon, on dépècerait les pouvoirs de l'évêque. Désormais, de bas en haut de l'échelle, le clergé compterait sur le seul gouvernement pour les promotions. En somme, une église domptée, domestiquée, articulée dans l'Etat comme le fonctionnarisme civil.

I am well satisfied upon the whole, that the offices of the Bishop \& His Coadjutor are necessary in Canada - and that they may be rendered extremely beneficial to his Majesty's Interests, but it cannot be doubted that the Bishop has not any claim of right to the authority which he now exercises. He is not only excluded by the 6th article of the Capitulation 
of Quebec and the 29, 30th \& 31 articles of the Capitulation of Montreal, but as his office was originally created in 1670 «to be held of and dependent upon the See of Rome » with the title of "Vicaire du Siège Apostolique », it is annihilated by the operation of the Statutes 26 th Hen 8 c.l. \& 1 . Eliz. c.l. particularly in the 16 th section of the latter by which all exercise of the Pope's authority or of any ecclesiastical authority derived from him is prohibited in England « and in all other Dominions which the Crown now had or might thereafter acquire ». The universal patronage of the Church \& all other rights of the Bishop's office have transferred to his Majesty by the law of conquest which vests in the conqueror of any state or province every rights of sovereignty and dominion possessed by its former masters. I conceive with great submission to your Excellency better judgment that it will be necessary for the Crown to assume that right of nominating the Bishop, the Coadjutor and the Parish priests which it assumed by the conquest of Canada, but has never yet exercised. The appointment \& removal of the parish priests and his successor the Coadjutor, will in no small degree contribute to the good conduct of the inferior clergy, all of whom will live in expectation of promotion to better livings should they merit them by good behaviour, ${ }^{14}$ while the more distinguished will regard elevation to episcopal dignity as an honor within their reach, attainable by loyalty \& exertions in support of Government.

Une telle politique tisonnera de nombreuses difficultés, vu l'importance numérique des catholiques. Ne sont-ils pas aussi Français ? Mais il faut drosser l'évolution actuelle. Un coup de force comporterait trop de risques. Mieux vaut se rabattre sur des moyens d'action moins manifestes: isolement du clergé local par l'exclusion des prêtres étrangers; résidence forcée et sur-

${ }^{14}$ Il est vrai qu'à l'intérieur d'une Eglise bien dotée, certains pourraient préférer la servilité dorée à la liberté. Mais les bénéfices, dans l'Eglise catholique, sont très maigres à cette époque - à l'exception de quelques cures. Jusqu'aux évêques qui doivent exercer un ministère paroissial, en contradiction avec le droit canon, pour assurer leur subsistance: Mgr Denaut, à Longueuil, et le coadjuteur Plessis, à Québec. Cette situation de fait atténue la force de l'exposé de Sewell. 
veillée de l'évêque et de son coadjuteur à Québec, sous prétexte d'efficacité et de centralisation administratives; reconnaissance officielle, par le Parlement de Londres, de la fonction épiscopale, juridiction absolue de la couronne sur le choix des candidats et sur la somme de pouvoirs ecclésiastiques à leur condescendre. Tout le patronage et les nominations aux bénéfices jailliraient évidemment du Roi. Celui-ci présenterait lui-même l'indult à l'évêque et le maintiendrait dans ses fonctions «selon son bon plaisir». Donc, autorité globale de la couronne:

The difficulties which will occur in the execution of this Idea, will be many and various - nineteen twentieths of the Inhabitants of Canada are Roman Catholics - \& Frenchmen - Their prejudices, religious and political, must be encountered, and that independent spirit in which the priesthood is too apparent must be subdued - To attempt it by force under such circumstances is to risk too much, recourse therefore must be had to other means, and I think means may be adopted less dangerous but equally certain ... [1 -$]$ To remove all immigrant priests ... enemies by birth, bigots, considering ... themselves martyrs... To leave the Canada clergy open to the counsels of such characters would at least be imprudent. [2-] To insist upon the constant residence of the Bishop and his coadjutor at Quebec for their conduct should at all times be under the immediate eye of Government. - The necessity of having the heads of each departments at the seat of Government would be to them a sufficient reason for this Requisition. [3 - ] To procure an Act of the Imperial Parliament recognizing the office of the Bishop, and of his Coadjutor but declaring them to be offices in the absolute appointment of the Crown, authorising then consecrating and remitting them to exercise such ecclesiastical powers as may be thought expedient. The same Act should declare the Patronage of all benefices whatever to be vested in his Majesty. That he should in all future cases present the Bishop's indult and the incumbent hold his cure during the Royal pleasure.

Naturellement, on fera miroiter des compensations. On persuadera l'évêque et son coadjuteur de l'intention de l'autorité 
civile de toujours considérer attentivement leur avis, de ne pas investir mais bien de consolider leur juridiction spirituelle. On les confrontera avec la nécessité inéluctable d'exécuter les instructions royales, quant aux nominations aux cures et autres sujets de juridiction temporelle. En échange, salaire conforme à leur situation, sièges dans les conseils :

It is not to be supposed that the Bishop ... in which such alterations are effected would be satisfied unless something more is done and his own dissatisfaction might by an artful mean in such a country as Canada be greatly extended beyond the circle of his immediate friends and connections. I am therefore humbly of opinion that it will be ... necessary to give the Bishop \& the Coadjutor in the first instance to understand that a proper attention will be paid on all occasions to their recommendations. That it is not the intention of Government to infringe any part of their Ecclesiastical authority on the contrary to establish it upon more permanent ground than that upon which it has hitherto stood - Yet they should clearly comprehend that the nomination to all offices must center in the Crown ! and that every other matter of temporal jurisdiction which they had hitherto exercised or claimed must necessarily be transferred to their Sovereign. At the same time as a compensation for the loss of their own country livings and patronage of Benefices and that increase of expenses which their removal to Quebec must necessarily occasion, an adequate pension should I think be offered to each of them with seats in the Executive and Legislative Councils.

This compensation would I conceive not only be requisite to insure the acquiescence and cooperation of the Bishop and Coadjutor in the proposed arrangements but a mean of sound Policy.

Sewell triture minutieusement cette notion de la «politisation » de l'évêque et du coadjuteur, démarche préalable à l'effondrement de leur ascendant sur les fidèles. Le catholicisme, en effet, interpose une puissance ecclésiastique distincte entre le prince et le peuple; ce qui disloque l'union parfaite et si nécessaire de l'Église et de l'État, telle qu'elle existe en Grande- 
Bretagne. Tolérer pareille distinction, c'est aiguillonner l'ambition romaine d'un empire spirituel. Au contraire, politiser les évêques, les engrener dans les affaires humaines, c'est lézarder cette domination sur les laïcs, pouvoir fondé justement sur leur caractère exclusivement spirituel. En politique, ils se rangeront du côté de l'autorité civile: d'elle sourdent leurs pouvoirs. En cas de schisme, ce dissentiment ne peut que militer en faveur du gouvernement; dans le cas contraire, recours aux sanctions spirituelles et au bras séculier. Sewell est peut-être machiavélique. Mais il ne joue pas à l'agneau; il ne jongle pas avec les circonvolutions. Il fonce résolument, dans un style incisif:

The general effect [de ses suggestions] is to diminish the importance of the Bishop and his Coadjutor in their Ecclesiastical capacities - and to me no means appears so certain the extreme ignorance of the Canadians considered as to make them temporal characters and pensioners of Government. - This consideration however apart, it must be remarked that the natural tendency of $R$. C. Principles is to create a distinct ecclesiastical power to intervene between the Prince \& the People. By which that perfect union of Church and State which as the example of England demonstrates constitutes the true interests of Government is prevented - . To suffer the Bishop \& his Coadjutor (mostly dignified ecclesiastics in this Province...) to remain as ecclesiastics only \& consequently distinct characters from Government is in my opinion to promote that tendency and support that peculiar spiritual jurisdiction \& influence, which the See of Rome has endeavoured at all times to establish.

To elevate the Bishop \& his Coadjutor to the Executive \& Lg. Councils is to change that Importance, which they now enjoy appropriate and distinct from Government for an importance in which government will pertake - and it cannot be feared that such an elevation will encrease their influence over the Inferior clergy and the members of their Church for it is at this moment as great as it can be and wholly uncontrolable. So far also as it relates to the members of the Church who are not of the Clergy it is founded wholly upon their spiritual character. 
By many they are owned \& considered solely as ecclesiastics, as more abstracted from the world \& therefore respected - to make them political characters and to hold them up to attack and criticism as men of the world, is to sap the very foundation of their influence.

A Bishop \& Coadjutor once embarked in public Politics will act like other individuals, their dependence upon the crown will ensure their support in all governmental measures and their spiritual authority will probably in all cases be sufficient to direct the inferior clergy. For the spirit of the Roman Catholic Religion exacts a rigid obedience to episcopal authority. Should the case however be otherwise and a schism take place between them, the Bishop is no longer formidables and if the power of nominating to all vacant benefices, to be held during pleasure, is assumed by the Crown there can be no apprehension that upon such a schism the conduct of the Parish priests would militate against government Should even this happen - Removals of the refractory and the censures of the Church in the hands of the Bishop, which under such a circumstance would be at the absolute command of the Crown would be amply sufficient for the restoration of good order. ${ }^{15}$

Sewell s'arc-boute ensuite à un autre argument, qui pare d'avance une objection des Britanniques craintifs. La collectivité catholique se sent piétinée par ce qui lui semble une injustice: l'acte de 1791 rembarre ses pasteurs de l'assemblée. Ceux-ci ne figurent pas non plus dans les conseils, où siège pourtant l'évêque d'une petite minorité religieuse. D'autre part, le clergé a prouvé maintes fois sa loyauté. Avec le temps, la jalousie et la méfiance pourraient grignoter ses bonnes dispositions. $\mathrm{Au}$ contraire, des faveurs nouvelles lui injecteraient encore plus de zèle et de reconnaissance. La présence de l'évêque et du

15 Il est temps d'exorciser ce vieux mythe anglo-saxon, à savoir que le Québec était « a priests-ridden country 》 après la conquête. Les Canadians voulurent brider le clergé pour l'utiliser à leurs fins. Et plus tard, si le clergé se hissa à une importance civile démesurée, c'est certainement à cause de la mutilation nationale irrémédiable de 1760 . Plus que tous autres, les Canadians devraient inhumer cette question. 
coadjuteur dans les conseils n'aurait rien de redoutable: il suffirait d'en accroître le nombre de membres, selon un large éventail d'opinions, de façon à les neutraliser les uns par les autres, au bénéfice de la couronne - diviser pour régner. Au pire, ces réformes ne peuvent nuire; plus probablement, elles enraieront à temps les maux actuels.

Independent of those reflections it must be evident, that the clergy of the Church of Rome and the Roman Catholics collectively are extremely jealous of the present total exclusion of the former from the Legislature of the Province. The Act $31 \mathrm{Geo}$ : III. c. 31 has put them out from the Lower House and the Crown has not as yet called one of them to the Upper - They consider their Clergy as tried subjects in 1775, 1794, $1796 \& 1797$, when nearly the whole \& particularly the superior clergy certainly exerted themselves in support of Government to their utmost - and as they form a greater proportion of the entire population of the Province they hold themselves entitled to the honor which has been conferred upon the Church of England whose members are comparably small whose Bishop has a seat in both Councils - . I make no comment upon this pretension, I only state the fact to show the disposition of the catholic mind in Canada, in which the clergy from vanity greatly partake, and ... if things are continued as they now stand, their jealousy and distrust of government will increase and their cordiality in its support diminish in proportion. On the contrary after the experience we have had of the conduct of the Canadian clergy in times of serious commotion, and the general tenor of their behaviour we may reasonably expect under more favor an increase of attachment \& spirited support and as both councils may be augmented and any faction therein balanced by new members at the pleasure of the Crown, little danger if any can be apprehended from a Bishop or Coadjutor. I am even convinced that their present influence over the Catholic members of the Legislature is greater than it would be if they themselves were members. Upon the whole, the admission of the Bishop \& his Coadjutor to the Legislative \& Executive Councils 
will in my belief be highly beneficial to the Interests of His Majesty's Government. But if it does not produce the positive advantages which I am led to expect, it will do no harm, and certainly prevent the increase of evils which if not checked must in time become important and highly prejudicial.

J. Sewell ${ }^{16}$

Il n'est pas improbable que Milnes aît pris connaissance de ce rapport. De toute façon, le 10 juin, il aborde brièvement le sujet dans sa correspondance avec le Colonial Office. Il n'a pas l'intention de disserter sur les causes de l'indépendance du clergé catholique. Mais fort de l'appui explicite du secrétaire d'Etat aux colonies, il promet de rajuster la situation par tous les moyens «that Prudence can suggest wherever a favorable moment presents itself $\gg .{ }^{17}$ Et en effet, les hauts fonctionnaires et le gouverneur ne rateront pas les occasions propices.

Déjà, le lieutenant-gouverneur a exigé poliment des Sulpiciens un mémoire détaillant leurs biens, leurs revenus, leurs noms, leur nombre, leurs règlements, etc. La réponse couvre les années 1795 à $1800 .{ }^{18}$ Ryland l'exhibera à Londres, lors de sa mission en 1811 et 1812 .

Sewell est comblé d'aise, lorsqu'il démontre, au bénéfice du lieutenant-gouverneur, les motifs d'une querelle entre l'évêque et le Séminaire de Québec au sujet de la possession d'une terre concédée en 1674 à Mgr de Laval. Les cours de Sa Majesté, vaticine le rusé procureur général, seront vraisemblablement saisies de l'affaire. Or, ni l'évêque ni le Séminaire n'a droit à cet héritage : vieux titres obscurs, concession présumément personnelle à $\mathrm{Mgr}$ de Laval et ses héritiers, etc. Situation taillée sur mesure pour la Couronne: elle croquera vraisemblablement le tout. ${ }^{19}$

\footnotetext{
$16 \mathrm{~J}$. Sewell à Milnes, Québec, 29 mai 1801, AC, MG. 23, Documents Sewell [GII], 10, v. 2: document no 2 [s.p.].

17 Milnes à Portland («Confidentielle et détachée 》), Québec, 10 juin 1801, AC, Q. 87-1: 95 .

$18 \mathrm{Ce}$ document se trouve dans R. Christie, History, 6: 41-48. Voir aussi AC, Documents St-Sulpice [M.G. 17], 1, 5: [s.p.].

19 Sewell [à Milnes], 1er août 1800, AC, R.G. 4, A1, $55: 45$.
} 
Vers le même temps, J.-H. Papineau divulgue à un sulpicien de Montréal l'objet d'une conversation qu'il a surprise entre Sewell et un autre personnage. Le procureur général aurait soutenu que « il n'y a pas à Montréal d'autres Sulpiciens que ceux qui ont été affiliés au Séminaire de Paris, et à qui le gouvernement a permis de venir; permission qui s'il ne la continue pas, il ne leur laissera pas de successeurs...», méthode commode pour râfler leurs biens..$^{20}$ La mainmise de l'Etat sur les biens des Jésuites était d'ailleurs récente.

À deux ou trois reprises, Ryland, le secrétaire sans humour de l'administrateur civil, avisa Mgr Plessis de déclarations antibritanniques proférées par des membres du clergé.. ${ }^{21}$ Sauf à une occasion, des enquêtes firent crouler l'accusation. Mais il faut noter ce harcèlement. D'autant plus que Milnes voulut s'enhardir davantage, à une autre reprise. Dans la paroisse de Terrebonne, on reprochait à un prêtre de fomenter le désordre et la division. Par Ryland, le lieutenant gouverneur fit mander à Mgr Plessis sa décision de le déplacer. L'évêque répondit immédiatement, sur un ton suave, qu'il avait «prévenu cette intention » et permuté lui-même le coupable à Verchères. Ce départ, espérait-il, ferait se résorber l'atmosphère troublée qui pesait sur Terrebonne. ${ }^{22}$ Deux bons escrimeurs ferraillaient. Tant que l'autorité se contentait de jouer, de feindre, ce n'était pas critique. Mais le jour allait venir où elle voudrait cesser de finasser avec un évêque également fûté.

Tous ces indices, considérés globalement, démontrent la volonté arrêtée du gouvernement de solutionner à son avantage la question religieuse. D'autant plus qu'ils se multiplieront avec les années. Sewell et derrière lui, Milnes, faillirent réussir dans leurs efforts, en 1805. A ce moment, ils tendirent un piège habile aux évêques. Mgr Denaut mordit craintivement à l'appât et signa une pétition priant le gouvernement d'《établir » l'église pièce 92.

20 J.-H. Papineau à M. Saulnier, ptre, [1800], AC, M.G. 17, 3, 5:

21 Par exemple, voir AC, R.G. 7, G. 14, 33: [s.p.].

$22 \mathrm{Mgr}$ Plessis à Ryland, Longueuil, 10 septembre 1801, AC, R.G. 4, A1, 56B: 156. 
catholique. ${ }^{23}$ Les circonstances tirèrent l'Église du pétrin et sauvèrent son autonomie: Milnes regagna l'Angleterre à l'été 1805; Mgr Denaut mourut quelques mois plus tard; Dunn, un revenant du «French Party », assermenta en vitesse l'évêque Plessis et un nouveau coadjuteur, Mgr Panet. Ce qui fit bisquer un Ryland exacerbé. Mais parallèlement à ce sursis, Sewell matraquait l'Église en cour d'appel, dans une cause-type sur la création de nouvelles paroisses. ${ }^{24}$ Plus que jamais, le clergé allait souffrir de sa précarité légale dans une colonie où le catholicisme n'était que « toléré » dans son culte. ${ }^{25}$

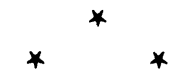

23 Pétition de Mgr Denaut, 18 juillet 1805, AC, Q. 98: 8. Aussi, R. Christie, History, 6: 279-280. Pour les entretiens Sewell-Plessis, voir D.C. (II) , 307-312; Rapport sur les Archives de la Province de Québec (1927-1928), 237-239, et ibid. (1931-1932), 231-234. \& Draft of Letters Patent for the Appointment of a Superintendent of the Romish Church in ... Lower Canada », Christie, History, 6: 308-311.

24 Cause Lavergne vs Bertrand, AC, Q. 115: 105 et suivantes; aussi Robert Christie, History, 6: 86-91.

Lavergne, résident d'une nouvelle paroisse (St-Léon), refusa de fournir le «pain bénit ». Poursuivi par le curé Bertrand, il perdit en cour inférieure, mais interjeta appel. Il fit intervenir l'avocat général Sewell. Ce dernier établit que le droit d'ériger toute nouvelle paroisse relevait exclusivement de la couronne, donc que la paroisse St-Léon (et implicitement, toutes les nouvelles paroisses créées par l'épiscopat depuis la conquête) n'existait pas; que la conquête avait aboli le poste d'évêque catholique et cédé au roi tous les pouvoirs de cette charge; «that no such office as Superintendent of the Romish Churches had at any time existed [legally] in this Province $\gg$, que l'ordonnance du gouverneur en conseil de 1791 relative à l'érection de nouvelles paroisses était illégale et nulle, etc. (AC, Q. 115: 105-109). Et dans un mémorandum, Sewell résumait sa pensée: \&...there is no Catholic Bishop of Quebec by law. His office became extinct at the conquest, and the patronage of the benefices... and the Edict of the Bishop, is devolved to his Majesty 》 (Cité par R. Christie, History, 6: 91). Lavergne triompha en appel. L'Etat voulait ainsi forcer l'Eglise à se soumettre à la prérogative royale, moyennant une reconnaissance légale de son existence (particulièrement en ce qui avait trait aux fonctions épiscopales, aux biens de l'Eglise, à la création de nouvelles paroisses, etc.).

En 1804, Ryland avait d'ailleurs prévu que le problème des nouvelles paroisses prouverait «to the heads of the Popish Clergy that they can hold no civil authority but through the medium of the Crown », les acculant ainsi à la nécessité d'accepter «such powers as the King in his wisdom might think fit to give them 》 (Ryland à -, 23 décembre 1804, cité par R. Christie, History, $6: 73$ ).

25 Devant l'accumulation des assauts sporadiques contre l'Eglise, particulièrement de 1791 à 1827 , on ne peut s'empêcher de sourciller à la lecture 
Quant au procureur général Sewell, on le trouve toujours sur la brèche, talonnant l'Église canadienne. En 1805, il presse Mgr Plessis de composer avec l'Etat, car «si vous ne profitez pas de cette occasion, vous n'en aurez jamais une autre semblable ». Hormis le couplet sur l'esprit libéral de Milnes, Sewell circonscrit nettement sa pensée, identique à celle de 1801:

... Il est absolument nécessaire que vous possédiez les moyens de protéger votre église; d'autre part, le gouvernement a besoin d'une bonne entente avec les ministres d'une église qu'il a reconnue par l'acte de Québec et, en même temps, il considère essentiel d'exercer son autorité sur eux... [Dans] les questions temporelles ou mixtes, vous devriez être sujet à l'autorité du roi... Le choix mutuel de la personne d'une part par l'évêque pour la prêtrise et d'autre part par la couronne pour la cure, est le moyen de maintenir l'équilibre entre l'un et l'autre... Une fois reconnu le chef de son département, l'évêque le sera de fait. Vous connaissez l'attention qui a toujours été et sera toujours accordée aux chefs de départements dans notre gouvernement... L'évêque devrait avoir suffisamment pour vivre dans une magnificence digne de son rang et le coadjuteur devrait recevoir des appointements proportionnels... Vous n'obtiendrez jamais quoi que ce soit qui n'est pas compatible avec les prérogatives de la couronne, ni aucun droit dont ne jouit pas un évêque de l'Eglise d'Angleterre. ${ }^{26}$

En 1810, Sewell renchérit encore sur ces propos: «La religion catholique a été établie au Canada... Les quatre cinquièmes de la population sont aussi catholiques romains et sous

des lignes suivantes: «Les Canadiens d'origine française se voient octroyer d'abord dans la pratique et ensuite d'une manière officielle par l'Acte de Québec, la liberté religieuse la plus complète et cela au moins soixante ans avant l'Angleterre et bien avant qu'eux-mêmes n'aient appris les rudiments de la tolérance en matière religieuse 》 (Fernand Ouellet, "Les Fondements historiques de l'option séparatiste dans le Québec 》, Canadian Historical Review, 43 (1962) : 187). Sans doute, de fait, une liberté illégale existait; mais combien fragile, combien menacée, sans fondements légaux et par conséquent, source constante d'insécurité et de tracasseries. Outre les faits, nombreux et probants, Mgr Plessis et Mgr Denaut, inquiets, se débondent ouvertement dans leurs lettres sur cette question. Ces faits et ces lettres ne sont-ils pas connus depuis longtemps ?

26 Entrevue Sewell-Plessis, D.C.(II), 307-312. 
la direction d'un clergé qui est établi par les lois mais refuse de reconnaître que le souverain est ou peut être investi du droit de suprématie. » Il faut donc - dans le cadre d'un vaste plan pour unir les Canadas et digérer les Canadiens - saper «l'influence du clergé catholique romain », par « la reprise et l'exercice $\mathrm{du}$ droit de nommer les titulaires à tous les bénéfices $\gg .^{27}$

Mgr Plessis accède au Conseil législatif en 1818. En 1823, le juge-en-chef défend encore ses principes théoriques. Mais «... l'état actuel de l'opinion me paraît exiger qu'elles [les instructions royales] soient retardées ... L'occasion propice pour mettre ces instructions à effet serait la nomination d'un nouvel évêque catholique romain. Avec un candidat pour la mître, elles pourraient alors être réglées par un «concordat...${ }^{28}$ L'année suivante, dans son projet d'union, Sewell s'écarte encore davantage de ses principes rigides de 1801. Sans doute, rien n'a entamé sa conviction que l'Église catholique est véritablement établie de fait. Mais la menace américaine et peut-être la sagesse de son âge lui confèrent plus de lucidité et de mesure: la conquête du pays par les Américains déboulonnerait l'Église de sa situation privilégiée; ainsi motivée par cet intérêt vital, le clergé n'inculquera-t-il pas au laïcat les sentiments appropriés de fidélité ? ${ }^{29}$ Sewell ne souffle plus mot de la subordination du clergé. Le réaliste politique a prévalu sur le théoricien légal.

\author{
JEAN-PIERRE WALLOT, \\ Département d'Histoire \\ Faculté des Lettres, \\ Université de Montréal.
}

27 Rapport du juge-en-chef Sewell au sujet de la réunion des provinces, [1810], AC, Q.112: 196. Traduction: D.C.(II), 405-410.

$28 \mathrm{~J}$. Sewell à Dalhousie, Québec, 19 janvier 1823, cité dans A. G. Doughty et N. Story, Documents relatifs à l'Histoire constitutionnelle du Canada (1819-1828) (Ottawa, 1935), 153.

29 Projet d'union générale dans l'Amérique du nord, par J. Sewell et John B. Robinson, [1824], ibid., 243-244. 